\title{
The Effect of Annealing Temperature and Reactive Gases on Optical Properties of $\mathrm{Cu}_{2} \mathrm{O}$ Thin Films
}

\author{
Radu Bunea, Ashwin Kumar Saikumar, Kalpathy Sundaram \\ University of Central Florida, Orlando, FL, USA \\ Email: rbunea@valenciacollege.edu
}

How to cite this paper: Bunea, R., Saikumar, A.K. and Sundaram, K. (2021) The Effect of Annealing Temperature and Reactive Gases on Optical Properties of $\mathrm{Cu}_{2} \mathrm{O}$ Thin Films. Materials Sciences and Applications, 12, 182-196.

https://doi.org/10.4236/msa.2021.125012

Received: March 22, 2021

Accepted: May 5, 2021

Published: May 8, 2021

Copyright ( 2021 by author(s) and Scientific Research Publishing Inc. This work is licensed under the Creative Commons Attribution International License (CC BY 4.0).

http://creativecommons.org/licenses/by/4.0/

\begin{abstract}
The $\mathrm{Cu}_{2} \mathrm{O}$ thin films were synthesized by using $\mathrm{RF}$ sputtering technique. Comparisons were made with films created by deposition at room temperature followed by thermal annealing between $100^{\circ} \mathrm{C}$ and $400^{\circ} \mathrm{C}$ and using different gases, oxygen $\left(\mathrm{O}_{2}\right)$ (oxidizing and reactive gas) and nitrogen $\left(\mathrm{N}_{2}\right)$ (inert gas), besides air. The thickness of the thin films was kept constant, around $2000 \AA$ (Angstrom). In addition, the RF power and pressure deposition were kept constant, as well. The thin films were evaluated for a range of wavelengths between $200 \mathrm{~nm}$ and $400 \mathrm{~nm}$ (Ultra Violet spectrum), $400 \mathrm{~nm}$ and $700 \mathrm{~nm}$ (Visible spectrum), $700 \mathrm{~nm}$ and $800 \mathrm{~nm}$ (Infrared spectrum) for both, optical transmittance and photoluminescence. From the experimental results, the higher annealing temperature and the introduction of nitrogen $\left(\mathrm{N}_{2}\right)$ gas produced the following results: the optical bandgap for the $\mathrm{Cu}_{2} \mathrm{O}$ was found to be $2.23 \mathrm{eV}$ and photoluminescence peaks were around $551 \mathrm{~nm}$ and 555 $\mathrm{nm}$, which matched the theoretical analyses. Overall, there was a decrease in the optical bandgap of the $\mathrm{Cu}_{2} \mathrm{O}$ from $2.56 \mathrm{eV}$ at room temperature to $2.23 \mathrm{eV}$ for the film annealed in nitrogen gas at $400^{\circ} \mathrm{C}$. This indicates that the $\mathrm{Cu}_{2} \mathrm{O}$ is a potential candidate in solar cell applications.
\end{abstract}

\section{Keywords}

$\mathrm{Cu}_{2} \mathrm{O}$ Thin Film, Optical Properties, Bandgap, Photoluminescence

\section{Introduction}

In general, metal-oxide semiconductors are very popular materials in numerous applications, such as solar cells [1]. Cuprous oxide $\left(\mathrm{Cu}_{2} \mathrm{O}\right)$ is a p-type semiconductor that has a high absorption coefficient and a low optical bandgap [2]. The intrinsic cuprous oxide $\left(\mathrm{Cu}_{2} \mathrm{O}\right)$ is present in abundance and has both low toxici- 
ty and cost. It has a cubic structure that has a direct optical bandgap between $2.10 \mathrm{eV}$ and $2.60 \mathrm{eV}$ [3]. These characteristics make the cuprous oxide a potential candidate for the manufacturing of low-cost, all-oxide solar cells. The optical properties of this material, like the bandgap and photoluminescence, are dependent on the method of film preparation and deposition [4]. $\mathrm{Cu}_{2} \mathrm{O}$ thin films can be synthesized by using a combination of either physical or chemical methods. The most popular examples are thermal oxidation, RF sputtering, DC sputtering, pulsed laser deposition, chemical vapor deposition, and electrochemical deposition [5]. In this paper, the effect of the variation of the annealing temperatures and introduction of the different gases was studied.

$\mathrm{Cu}_{2} \mathrm{O}$ is the known copper oxide structure that has $\mathrm{Cu}^{1+}$ ionization and formed in a cuprite structure with a lattice parameter of $\mathrm{a}=4.268 \AA$ (Angstrom), with a space group of cubic geometry and octahedral Pn-3m symmetry. When the thin film is annealed, it causes the changes in the crystal structure's ionic pattern and its bonding properties [6].

The defect concentration in the cuprous oxide $\left(\mathrm{Cu}_{2} \mathrm{O}\right)$ thin films can be reduced through several processes. A few examples are annealing or growth in a controlled environment, passivation using a cyanide treatment, or hydrogen diffusion [7]. Raj Kumar et al. [7] chose to introduce hydrogen ions during deposition (passivation of materials surface by hydrogen) and annealing (post deposition) of the $\mathrm{Cu}_{2} \mathrm{O}$ thin film in hydrogen ambient atmosphere at different temperatures $\left(100^{\circ} \mathrm{C}\right.$ through $\left.600^{\circ} \mathrm{C}\right)$. The deposition method was DC magnetron sputtering at $400^{\circ} \mathrm{C}$ temperature and hydrogen ion was at $900^{\circ} \mathrm{C}$ [7]. The results obtained for the optical bandgap of the $\mathrm{Cu}_{2} \mathrm{O}$ film varied between $2.45 \mathrm{eV}$ to $2.55 \mathrm{eV}$ [7]. In our case, the method chosen for improving the quality of the $\mathrm{Cu}_{2} \mathrm{O}$ thin films was annealing at different temperatures post deposition.

The $\mathrm{Cu}_{2} \mathrm{O}$ forms in a unique cubic crystal structure where $\mathrm{Cu}^{+}$ions occupy one-half of the tetrahedral sites of a body-centered cubic packing of $\mathrm{O}^{2-}$ ions. The $\mathrm{Cu}_{2} \mathrm{O}$ particles tend to have a morphology exposing $\{100\},\{111\}$, and $\{110\}$ crystal facets. The intrinsic p-type conduction of $\mathrm{Cu}_{2} \mathrm{O}$ is believed to originate from copper vacancies acting as a shallow acceptor level located 0.2 to $0.3 \mathrm{eV}$ above the valence band maximum. Due to earth-abundant constituent elements, low cost and toxicity, the $\mathrm{Cu}_{2} \mathrm{O}$ can be used in various applications like solar cells, photo-catalysts, and as a thermoelectric material (direct conversion of waste heat into electricity) [8].

For practical applications of $\mathrm{Cu}_{2} \mathrm{O}$, it is important to consider the stress in the films caused by the substrate. This will affect the electrical and optical properties of the film. A compressive or tensile stress in a film is developed due to the mismatch of the lattice constant or the thermal expansion coefficient between the film and the substrate [7]. If glass is used as a substrate, because it is amorphous, the first mechanism is negligible. The films are not epitaxial grown on the substrate. The thermal expansion coefficient of $\mathrm{Cu}_{2} \mathrm{O}\left(\alpha_{f}=1.6 \times 10^{-6} \mathrm{~K}^{-1}\right)$ is much smaller than that of the glass substrate $\left(\alpha_{s}=8 \times 10^{-6} \mathrm{~K}^{-1}\right)$ [7]. Thus, $\mathrm{Cu}_{2} \mathrm{O}$ films deposited on the glass substrate at an elevated temperature are sub- 
jective to a compressive stress. In our case, the thin film deposition occurs at room temperature; hence, the impact of the compression stress is negligible.

\section{Experimental Procedure}

In this research, thin films of $\mathrm{Cu}_{2} \mathrm{O}$ were deposited on glass slides that were thoroughly cleaned using acetone, methanol and de-ionized water. The $\mathrm{Cu}_{2} \mathrm{O}$ films were deposited from a 2 -inch powder pressed target with a purity of $99.5 \%$ using RF magnetron sputtering technique. The sputter depositions were done in an in-house built sputtering system after a constant base pressure of $4 \times 10^{-5}$ Torr was achieved between each deposition. $\mathrm{Cu}_{2} \mathrm{O}$ films with constant thickness of $2000 \AA$ (Angstrom) were deposited at room temperature using Ar (argon) as the only sputtering gas. The RF power, argon flow and chamber pressure were kept constant for all depositions at 10 SCCM (standard cubic centimeter per minute), $10 \mathrm{mTorr}$ and $50 \mathrm{~W}$ respectively. The film thicknesses were identified using a Dektak 150 profilometer. Three sets of $\mathrm{Cu}_{2} \mathrm{O}$ films were made by systematically annealing for thirty minutes in an isotemp programmable muffle furnace at temperatures of $100^{\circ} \mathrm{C}$ to $400^{\circ} \mathrm{C}$ in the presence of oxygen $\left(\mathrm{O}_{2}\right)$, nitrogen $\left(\mathrm{N}_{2}\right)$ and air respectively. The gas flow into the annealing furnace was kept constant at 100 SCCM (standard cubic centimeter per minute).

The optical transmissions of the deposited $\mathrm{Cu}_{2} \mathrm{O}$ thin films were measured in a Carry 100 UV-Vis spectrophotometer from Agilent Technologies. The optical transmission was measured between 200 to $800 \mathrm{~nm}$, however, due to UV absorption only 350 to $800 \mathrm{~nm}$ results were analyzed. The optical bandgaps of the $\mathrm{Cu}_{2} \mathrm{O}$ films were identified from the transmission data using the Tauc plot method.

The photoluminescence measurements were recorded using a Flame spectrometer from Ocean Insight (formerly known as Ocean Optics) with a wavelength range from $200 \mathrm{~nm}$ to $850 \mathrm{~nm}$. The optical resolution of the spectrometer was $1.33 \mathrm{~nm}$ at full width half $\max$ (FWHM). The detector was a linear silicon CCD array with 2048 pixels and an entrance slit of $25 \mu \mathrm{m}$. The software used in association with the spectrometer was the Ocean View from the same company (Ocean Insight). The excitation source was a ThorLabs UV laser diode (L375P70MLD at $375 \mathrm{~nm}$ ). A $1000 \mu \mathrm{m}$ fiber optic patch cable (SMA to SMA) from ThorLabs with a numerical aperture of 0.50 completed the setup.

\section{Results and Discussion}

The $\mathrm{Cu}_{2} \mathrm{O}$ thin films had different levels of transparency as a function of annealing temperature (room temperature (RT) - semi-transparent to high temperature $\left(400^{\circ} \mathrm{C}\right)$-close to opaque). The thin films had an overall strong absorption in the UV region (between $200 \mathrm{~nm}$ and $375 \mathrm{~nm}$ ). The optical transmission spectrums for the $\mathrm{Cu}_{2} \mathrm{O}$ thin films annealed in different mediums (air, oxygen, and nitrogen) are shown in Figures 1-3.

The transmission spectrum for the first series of $\mathrm{Cu}_{2} \mathrm{O}$ thin films (room temperature and annealed in air) is shown in Figure 1. 


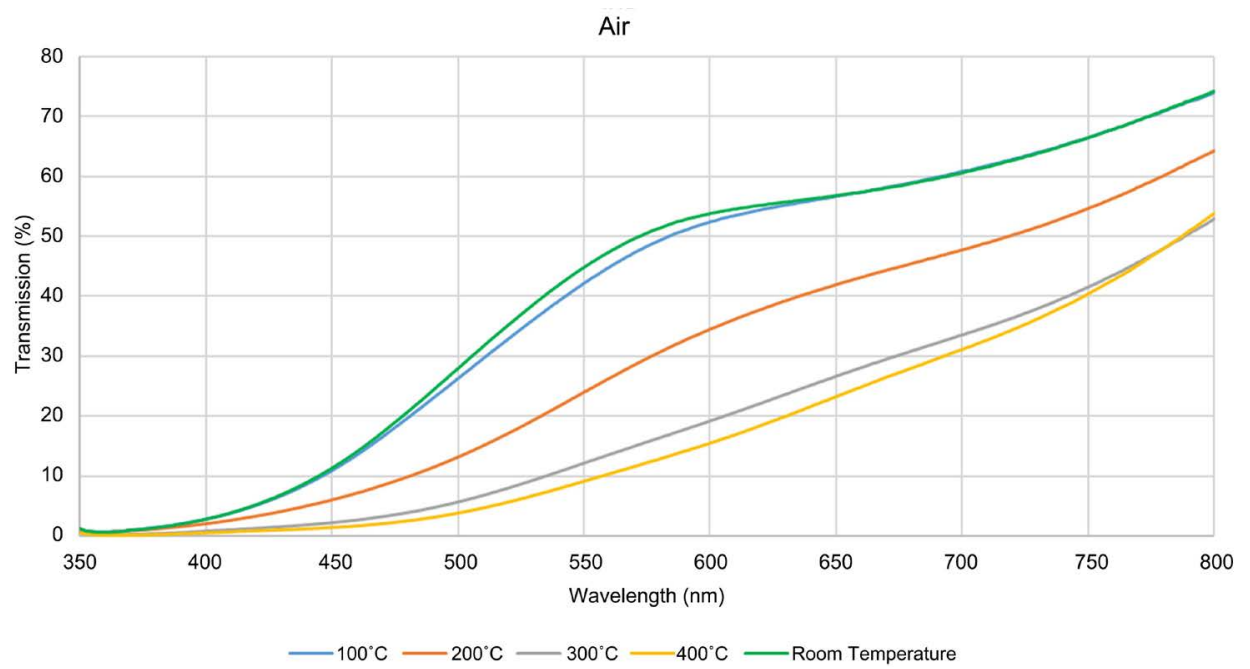

Figure 1. Spectra of $\mathrm{Cu}_{2} \mathrm{O}$ thin films annealed in air.

$\mathrm{O}_{2}$

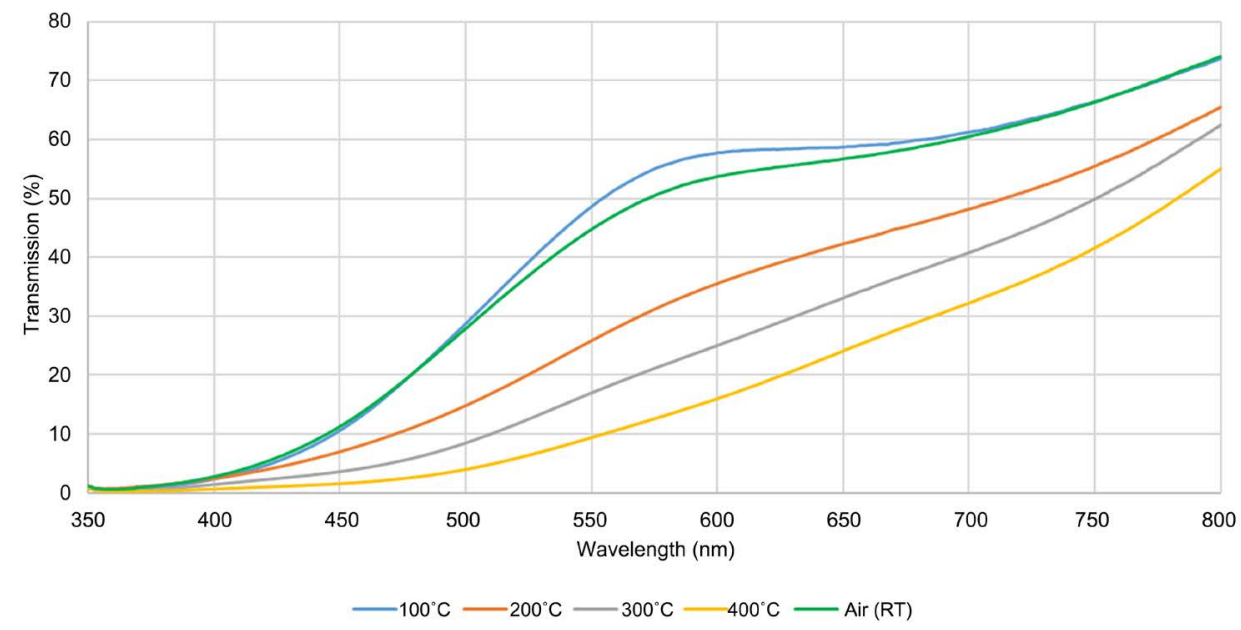

Figure 2. Spectra of $\mathrm{Cu}_{2} \mathrm{O}$ thin films annealed in $\mathrm{O}_{2}$ reactive gas.

$\mathrm{N}_{2}$

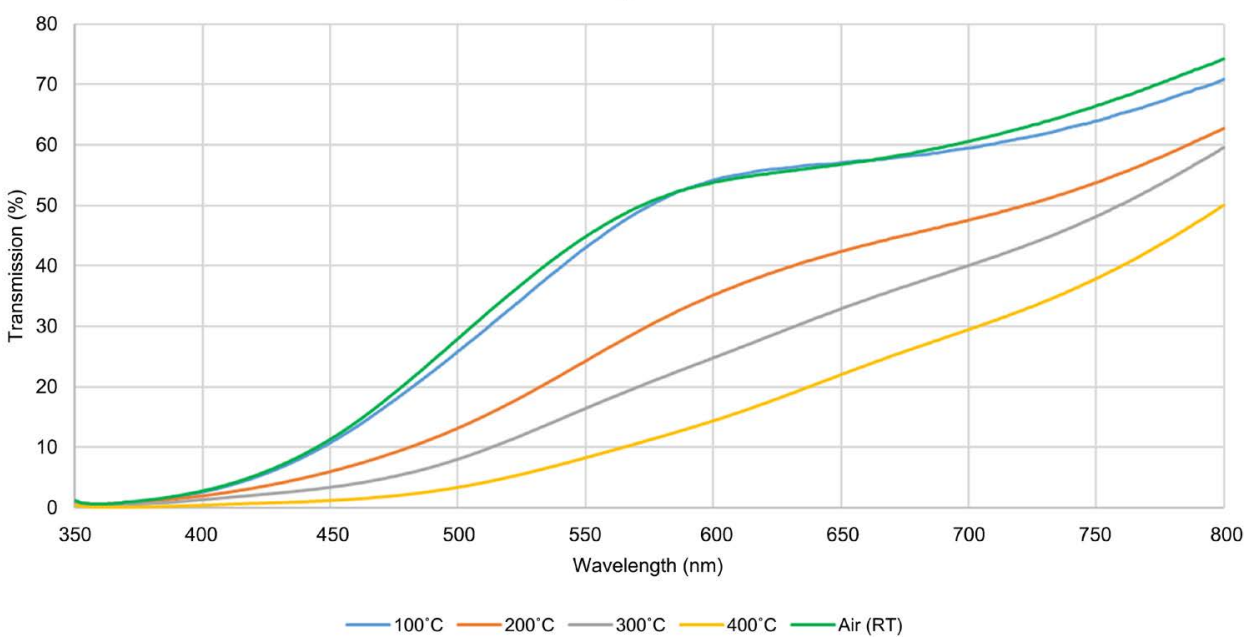

Figure 3. Spectra of $\mathrm{Cu}_{2} \mathrm{O}$ thin films annealed in $\mathrm{N}_{2}$ inert gas. 
The transmission varied as function of the annealing temperature (room temperature (RT) - maximum transmission of $74.16 \%$ at $800 \mathrm{~nm}$ to high temperature $\left(400^{\circ} \mathrm{C}\right)$ - maximum transmission of $53.84 \%$ at $\left.800 \mathrm{~nm}\right)$. A similar behavior, the decrease in optical transmission as a function of annealing temperature increase, was observed at the optical bandgap (555 nm). At room temperature (RT) - maximum transmission of $46.14 \%$ to high temperature $\left(400^{\circ} \mathrm{C}\right)$-maximum transmission of $9.80 \%$.

Note: The values for the actual percentages for the optical transmission with respect of the wavelength were obtained from the data provided by the Carry software.

The transmission for the thin film deposit at room temperature and the film annealed in air at $100^{\circ} \mathrm{C}$ is very similar with a slight decrease between $500 \mathrm{~nm}$ and $600 \mathrm{~nm}$ for the annealed film. This can be associated with the temperature impact on the structure of the film.

The transmission spectrum for the second series of $\mathrm{Cu}_{2} \mathrm{O}$ thin films (room temperature and annealed in oxygen $\left(\mathrm{O}_{2}\right)$ ) is shown in Figure 2.

The transmission varied as a function of the deposition temperature (room temperature $(\mathrm{RT})$ - maximum transmission of $74.16 \%$ at $800 \mathrm{~nm}$ to high temperature $\left(400^{\circ} \mathrm{C}\right)$ - maximum transmission of $55.07 \%$ at $\left.800 \mathrm{~nm}\right)$. A similar behavior, the decrease in optical transmission as a function of deposition temperature increase, was observed at the optical bandgap (555 nm). At room temperature (RT) - maximum transmission of $46.14 \%$ to high temperature $\left(400^{\circ} \mathrm{C}\right)$-maximum transmission of $9.97 \%$. The transmission for the film annealed in oxygen was slightly increased, in comparison with the film deposit at room temperature, between the $520 \mathrm{~nm}$ to $670 \mathrm{~nm}$. For this portion of the visible spectrum, the presence of oxygen in the annealed chamber, allow of the change in structure of the film making it more transparent, hence the somewhat higher transmission percentage.

The transmission spectrum for the third series of $\mathrm{Cu}_{2} \mathrm{O}$ thin films (room temperature and annealed in nitrogen $\left(\mathrm{N}_{2}\right)$ ) is shown in Figure 3.

The transmission varied as a function of the deposition temperature (room temperature (RT) - maximum transmission of $74.16 \%$ at $800 \mathrm{~nm}$ to high temperature $\left(400^{\circ} \mathrm{C}\right)$ - maximum transmission of $50.07 \%$ at $\left.800 \mathrm{~nm}\right)$. A similar behavior, the decrease in optical transmission as a function of deposition temperature increase, was observed at the optical bandgap $(555 \mathrm{~nm})$. At room temperature (RT) - maximum transmission of $46.14 \%$ to high temperature $\left(400^{\circ} \mathrm{C}\right)$-maximum transmission of $8.93 \%$. The transmission for the air deposited film at room temperature was slightly higher, in comparison to the film annealed at $100^{\circ} \mathrm{C}$ in nitrogen, between $470 \mathrm{~nm}$ and $560 \mathrm{~nm}$ (visible spectrum), and lower between 700 $\mathrm{nm}$ and $800 \mathrm{~nm}$ (infrared spectrum). This shows the impact of nitrogen on the thin film at the longer wavelengths. The decrease in the transmission is direct proportional with the increase in absorption.

The results obtained for the optical transmission at different temperatures were tabulated in Table 1: 
Table 1. $\mathrm{Cu}_{2} \mathrm{O}$ Thin Films optical transmission results.

\begin{tabular}{|c|c|c|c|c|c|c|}
\hline \multirow{2}{*}{$\begin{array}{c}\text { Annealing } \\
\text { Medium }\end{array}$} & \multirow{2}{*}{ Wavelength } & \multicolumn{5}{|c|}{ Transmission } \\
\hline & & RT (no annealing) & $100^{\circ} \mathrm{C}$ & $200^{\circ} \mathrm{C}$ & $3000^{\circ} \mathrm{C}$ & $400^{\circ} \mathrm{C}$ \\
\hline Air & & & $73.99 \%$ & $64.25 \%$ & $52.88 \%$ & $53.84 \%$ \\
\hline $\mathrm{O}_{2}$ & 800 nm (IR) & $74.16 \%$ & $73.70 \%$ & $65.48 \%$ & $62.35 \%$ & $55.07 \%$ \\
\hline $\mathrm{N}_{2}$ & & & $70.84 \%$ & $62.69 \%$ & $59.51 \%$ & $50.07 \%$ \\
\hline Air & & & $43.46 \%$ & $25.10 \%$ & $12.91 \%$ & $9.80 \%$ \\
\hline $\mathrm{O}_{2}$ & $555 \mathrm{~nm}$ (VIS) & $46.14 \%$ & $50.14 \%$ & $29.97 \%$ & $17.87 \%$ & $9.97 \%$ \\
\hline $\mathrm{N}_{2}$ & & & $44.50 \%$ & $25.46 \%$ & $17.28 \%$ & $8.93 \%$ \\
\hline Air & & & $2.74 \%$ & $1.99 \%$ & $0.88 \%$ & $0.60 \%$ \\
\hline $\mathrm{O}_{2}$ & $400 \mathrm{~nm}(\mathrm{UV})$ & $2.81 \%$ & $2.28 \%$ & $2.44 \%$ & $1.51 \%$ & $0.59 \%$ \\
\hline $\mathrm{N}_{2}$ & & & $2.18 \%$ & $1.94 \%$ & $1.31 \%$ & $0.49 \%$ \\
\hline
\end{tabular}

Overall, the results indicated a decrease in optical transmission as a function of increasing the annealing temperatures. Furthermore, the change of the medium in the annealing chamber affected the optical transmission. Air as a annealing medium had the minimum impact of the thin film with the lower results observed for the thin films annealed in the nitrogen gas at $400^{\circ} \mathrm{C}(8.93 \%$ at 555 $\mathrm{nm})$.

Ozaslan et al. [6] deposited $\mathrm{Cu}_{2} \mathrm{O}$ on a glass substrate at $70^{\circ} \mathrm{C}$ by the SILAR (Successive Ionic Layer Adsorption Reaction) method. After the deposition the thin films were annealed in air at different temperatures between $100^{\circ} \mathrm{C}$ and $500^{\circ} \mathrm{C}$. The thickness of the film was determined by calculations using the gravimetric weighting method and found to be $488 \mathrm{~nm}$. The researchers found that the optical transmission value of copper oxide thin film to be $37 \%$ (at $550 \mathrm{~nm}-$ center of visible spectrum), the percentage dropped to $33 \%$ for the film annealed at $100^{\circ} \mathrm{C}$, and dropped even further to $23 \%$ for the annealing temperature of $300^{\circ} \mathrm{C}$.

The same behavior was detected from the thin films created for this paper. From the three series of films deposited, it was observed that the increase in annealing temperature created a more opaque film that minimized the optical transmission. In Figure 4, the graph shows the comparison between the transmissions in the three thin films annealed at $400^{\circ} \mathrm{C}$.

The transmission was minimum between $350 \mathrm{~nm}$ and $383 \mathrm{~nm}$ (UV spectrum) and less than $10 \%$ up to $556 \mathrm{~nm}$ (VIS spectrum). Overall, the lowest transmission (highest absorption) was observed in the last series of films at the highest annealing temperature $\left(400^{\circ} \mathrm{C}\right)$ in the presence of $\mathrm{N}_{2}$ gas.

The absorption coefficient of the thin film was determined using the following formula (Equation (1)) [9]:

$$
\sigma_{\lambda}=\frac{-\ln (T)}{t}
$$

where $\sigma_{\lambda}=$ absorption coefficient, $T=$ optical transmission, and $t=$ thickness of 


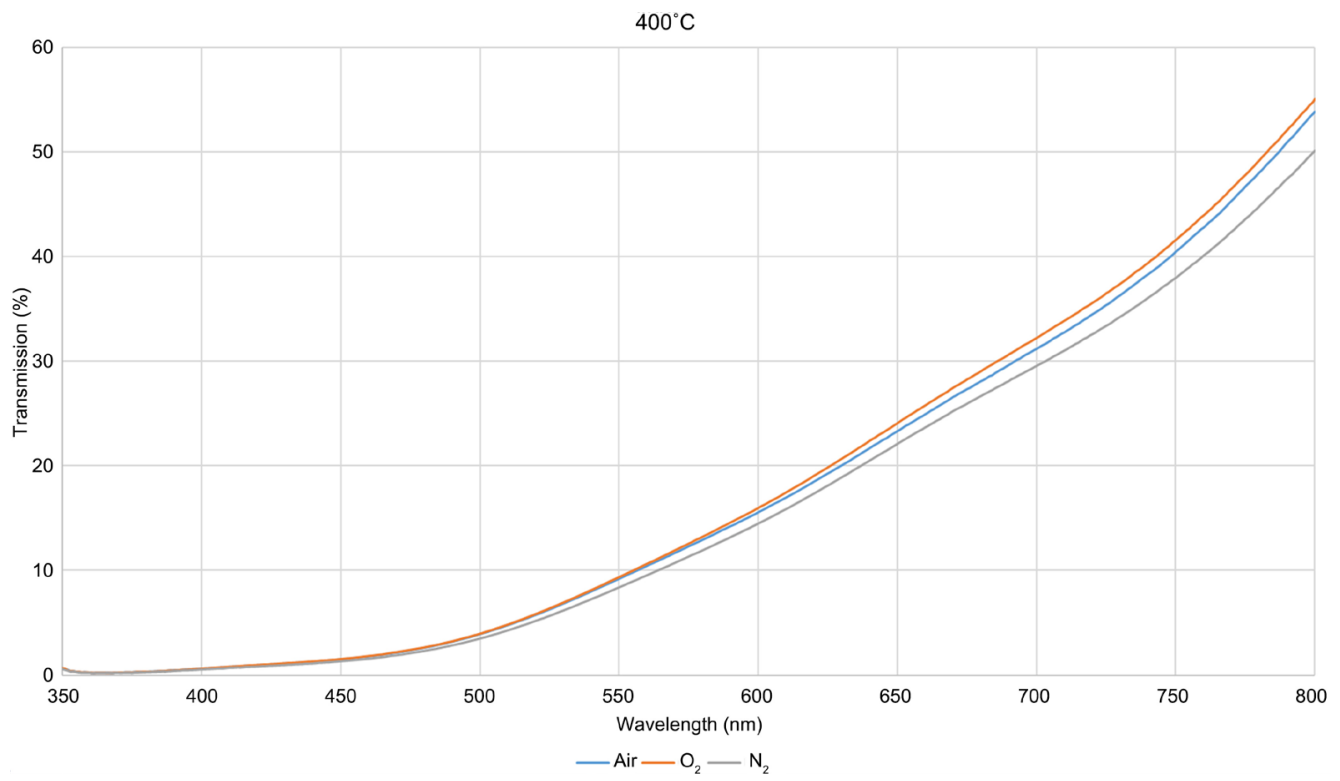

Figure 4. Spectra of $\mathrm{Cu}_{2} \mathrm{O}$ thin films annealed at $400^{\circ} \mathrm{C}$.

the film. The absorption coefficient was used to calculate the optical bandgap in the Tauc plot. The Tauc plot was graphed by fitting the data into this equation (Equation (2)) [10]:

$$
\left(\sigma_{\lambda} \cdot h v\right)^{2}=B\left(h v-E_{g}\right)
$$

where $h v=$ photon energy, $B=$ constant factor, and $E_{g}=$ optical bandgap.

The Tauc plot for the absorption coefficient is shown in Figures 5-9 below from room temperature to $400^{\circ} \mathrm{C}$ :

The optical bandgap is extracted by extrapolating the linear region of the Tauc curve to the $\mathrm{x}$-axis. The $\mathrm{x}$-intercept provides the value of the optical bandgap for the $\mathrm{Cu}_{2} \mathrm{O}$ thin films. The curve for the film deposited in $\mathrm{O}_{2}$ almost overlaps the film deposited in air and as a result, no significant difference was observed in the optical bandgap, $2.23 \mathrm{eV}$. The bandgap for the film annealed in $\mathrm{N}_{2}$ was $2.25 \mathrm{eV}$. The optical bandgap for the $\mathrm{Cu}_{2} \mathrm{O}$ thin film varied between $2.58 \mathrm{eV}$ (at room temperature) to $2.23 \mathrm{eV}$ (at $400^{\circ} \mathrm{C}$ ). The bandgap values in Table 2 are in agreement with the theoretical and experimental values found in the literature, $2.23 \mathrm{eV}$ band-gap [11], 2.10 - $2.30 \mathrm{eV}$ [12].

Sai Guru Srinivasan et al. [3] deposited $\mathrm{Cu}_{2} \mathrm{O}$ thin films on a glass substrate by $\mathrm{RF}$ reactive (controlled argon and oxygen atmosphere) sputtering at room temperature with various deposition times $(1,3$, and 5 minutes) which corresponded to the following thicknesses: 112, 304, and $498 \mathrm{~nm}$. The optical bandgaps for the three $\mathrm{Cu}_{2} \mathrm{O}$ thin films were $2.54,2.41$, and $2.12 \mathrm{eV}$. The results show a decrease in the optical bandgap with the increase in the film thickness. The conclusion was that the particle size and lattice defects have a direct influence on the optical bandgap value. The growth in the grain size was observed as a function of high surface to volume ratio of the film with lower thickness. In addition, lattice defects were observed due to oxygen vacancy [3]. 


\section{Room Temperature}

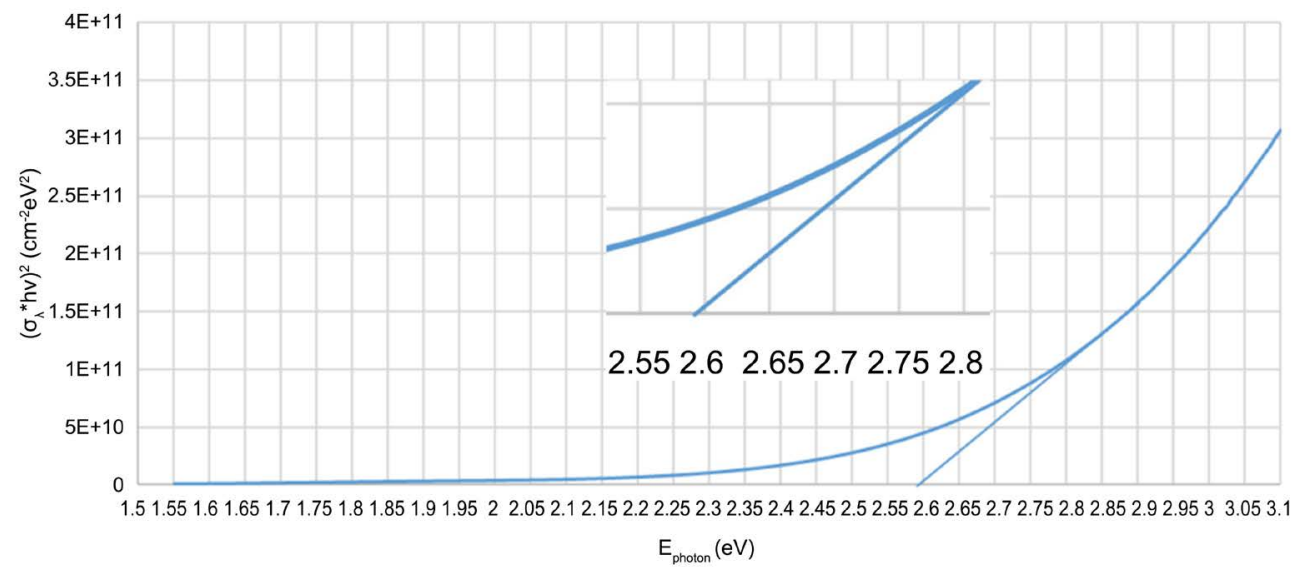

- Air

Figure 5. $\mathrm{Cu}_{2} \mathrm{O}$ thin films optical bandgap (room temperature).

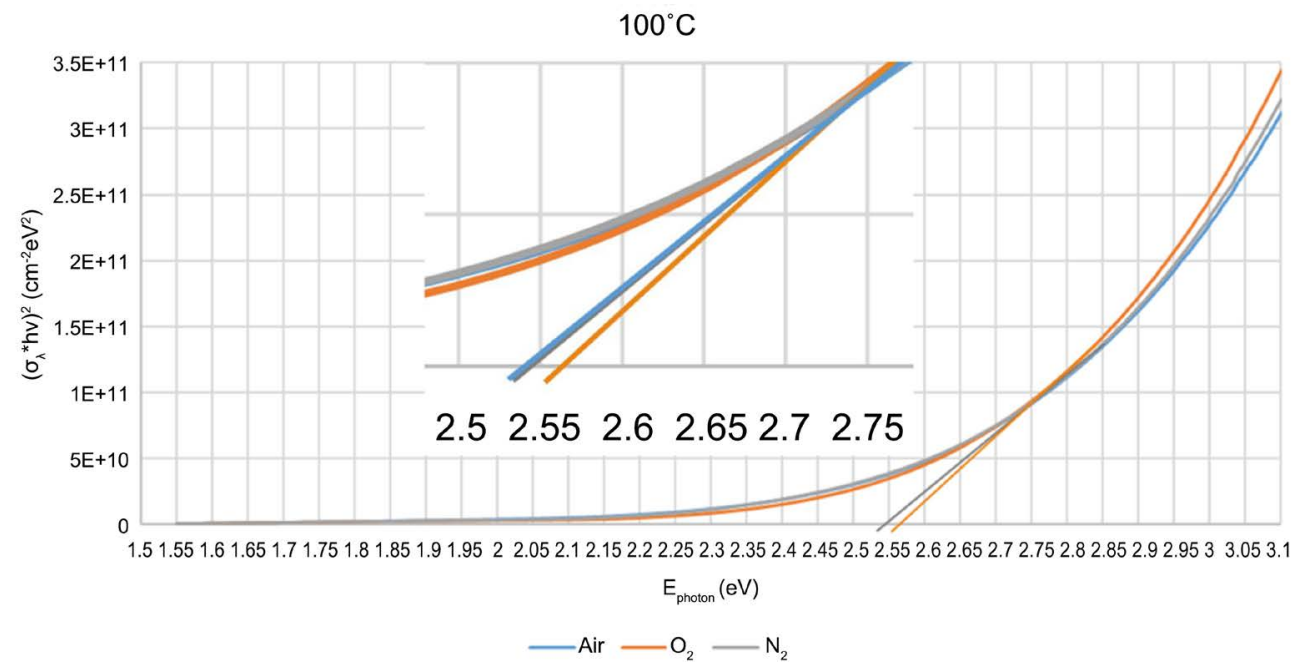

Figure 6. $\mathrm{Cu}_{2} \mathrm{O}$ thin films optical bandgap (annealed at $100^{\circ} \mathrm{C}$ ).

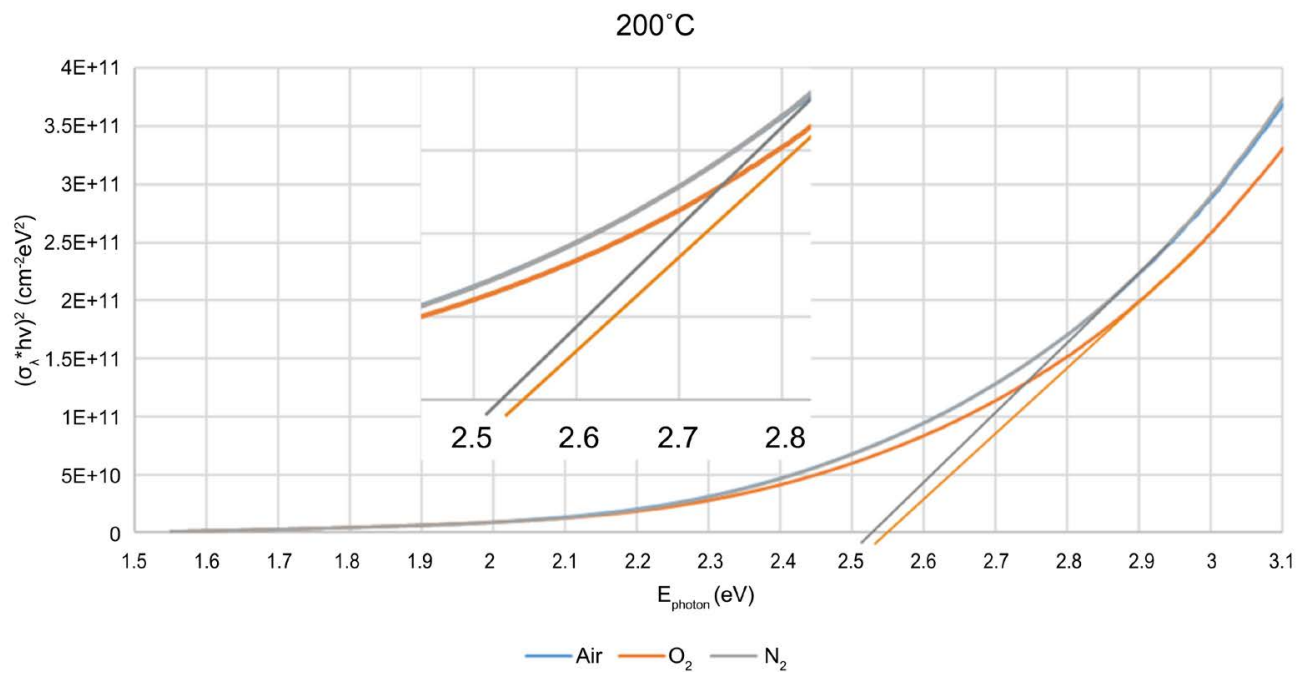

Figure 7. $\mathrm{Cu}_{2} \mathrm{O}$ thin films optical bandgap (annealed at $200^{\circ} \mathrm{C}$ ). 
$300^{\circ} \mathrm{C}$

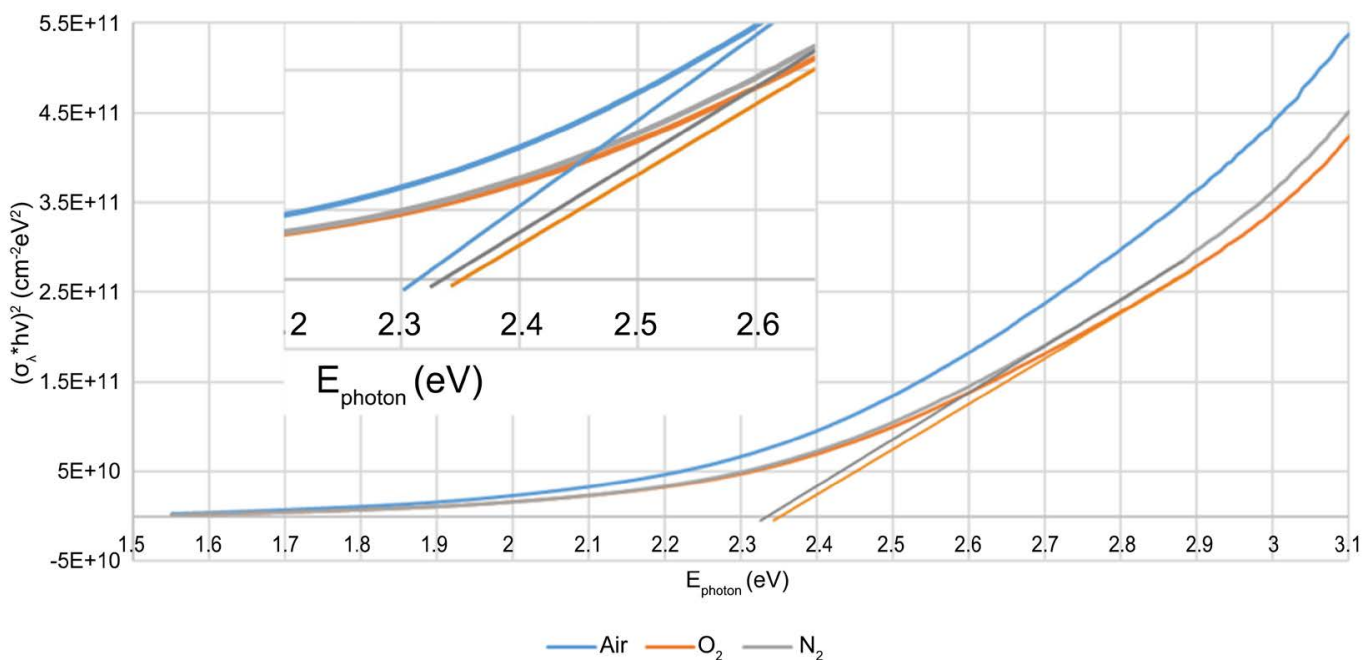

Figure 8. $\mathrm{Cu}_{2} \mathrm{O}$ thin films optical bandgap (annealed at $300^{\circ} \mathrm{C}$ ).

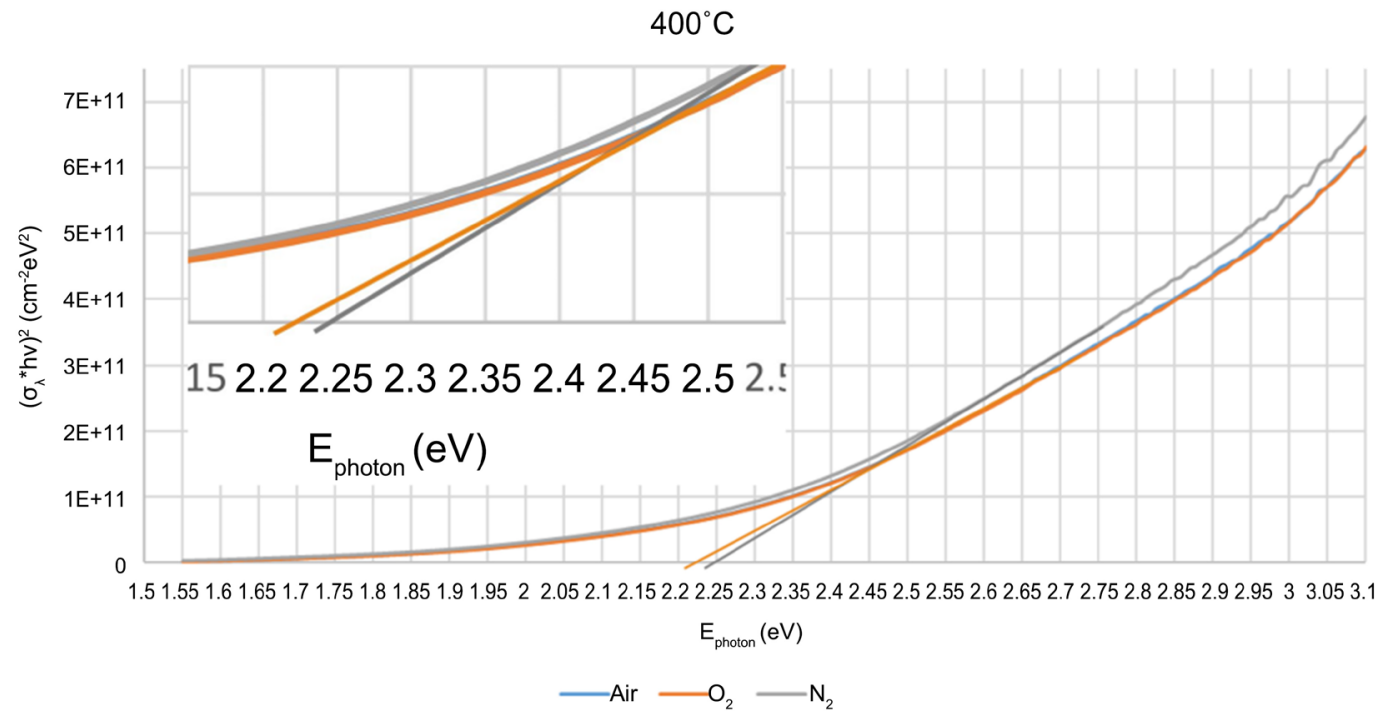

Figure 9. $\mathrm{Cu}_{2} \mathrm{O}$ thin films optical bandgap (annealed at $400^{\circ} \mathrm{C}$ ).

Table 2. $\mathrm{Cu}_{2} \mathrm{O}$ thin films optical bandgap values.

\begin{tabular}{|c|c|c|c|}
\hline \multirow{2}{*}{ Temperature } & \multicolumn{3}{|c|}{ Optical Bandgap } \\
\hline & Air & $\mathrm{O}_{2}$ & $\mathrm{~N}_{2}$ \\
\hline Room Temperature & & $2.58 \mathrm{eV}$ & \\
\hline $100^{\circ} \mathrm{C}$ & $2.53 \mathrm{eV}$ & $2.54 \mathrm{eV}$ & $2.56 \mathrm{eV}$ \\
\hline $200^{\circ} \mathrm{C}$ & $2.53 \mathrm{eV}$ & $2.54 \mathrm{eV}$ & $2.53 \mathrm{eV}$ \\
\hline $300^{\circ} \mathrm{C}$ & $2.32 \mathrm{eV}$ & $2.35 \mathrm{eV}$ & $2.34 \mathrm{eV}$ \\
\hline $400^{\circ} \mathrm{C}$ & $2.23 \mathrm{eV}$ & $2.23 \mathrm{eV}$ & $2.25 \mathrm{eV}$ \\
\hline
\end{tabular}

The increase in the annealing temperature affected the properties of the $\mathrm{Cu}_{2} \mathrm{O}$ thin films and one of their effects was a decrease in the optical bandgap. If the 
annealing temperature is increased even higher than $400^{\circ} \mathrm{C}$, an even lower bandgap for the $\mathrm{Cu}_{2} \mathrm{O}$ thin films can be achieved. Ozaslan et al. [6] found that the bandgap for the $\mathrm{Cu}_{2} \mathrm{O}$ thin films was reduced from $2.57 \mathrm{eV}$ (at $70^{\circ} \mathrm{C}$ ) to 1.91 $\mathrm{eV}\left(\right.$ at $500^{\circ} \mathrm{C}$ ) with the increase in temperature.

The photoluminescence measurement is shown in Figures 10-14 below (from room temperature to $400^{\circ} \mathrm{C}$ ):

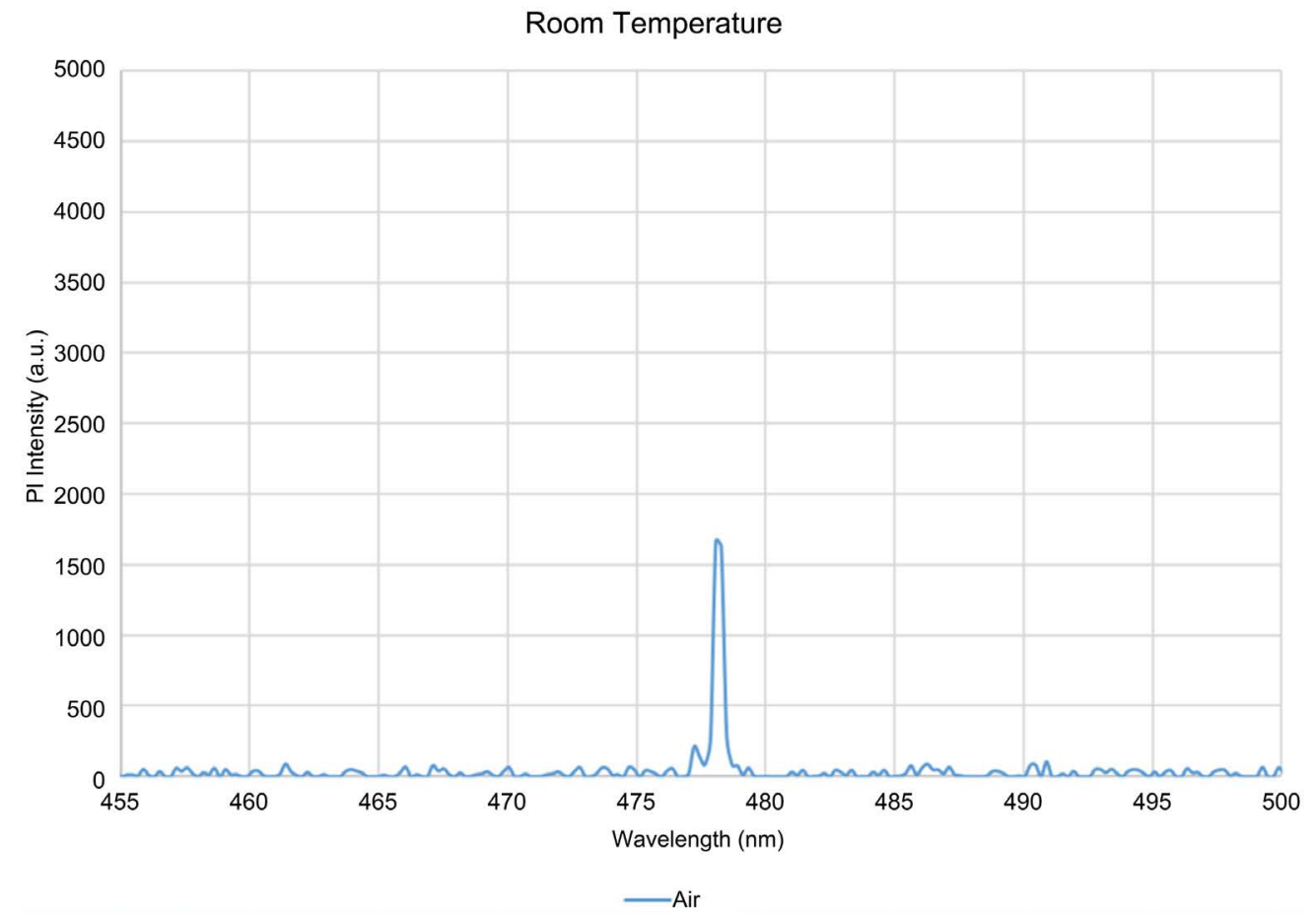

Figure 10. PL Spectra of $\mathrm{Cu}_{2} \mathrm{O}$ thin films (room temperature).

$100^{\circ} \mathrm{C}$

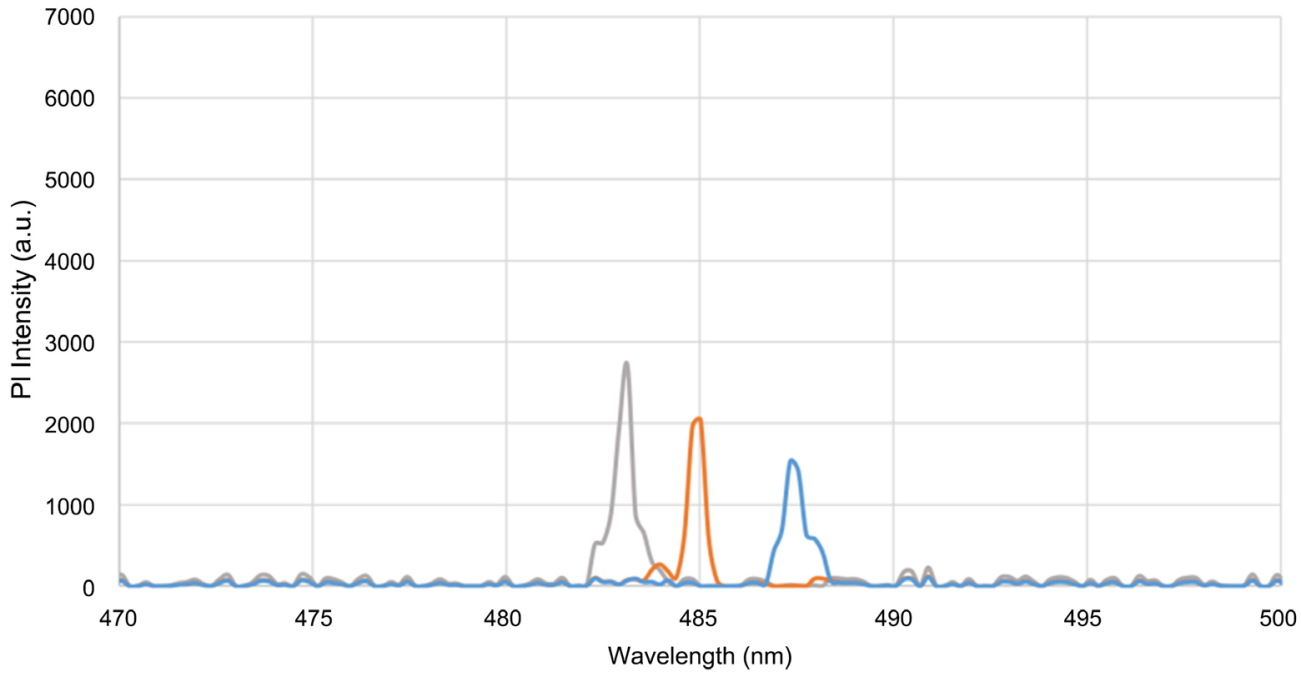

$-\mathrm{N}_{2}-\mathrm{O}_{2}-$ Air

Figure 11. PL Spectra of $\mathrm{Cu}_{2} \mathrm{O}$ thin films (annealed at $100^{\circ} \mathrm{C}$ ). 
$200^{\circ} \mathrm{C}$

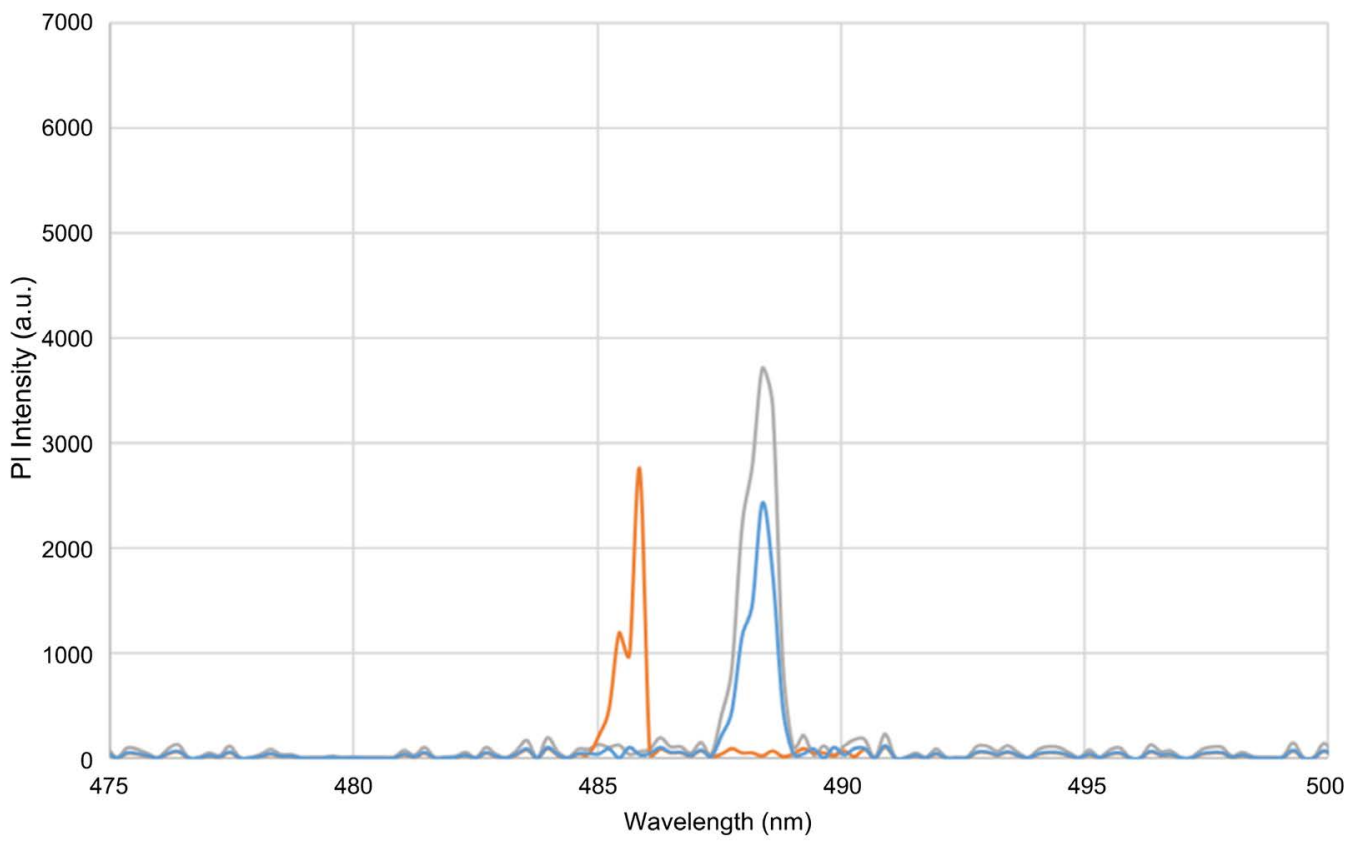

$-\mathrm{N}_{2}-\mathrm{O}_{2}-$ Air

Figure 12. PL Spectra of $\mathrm{Cu}_{2} \mathrm{O}$ thin films (annealed at $200^{\circ} \mathrm{C}$ ).

\section{$300^{\circ} \mathrm{C}$}

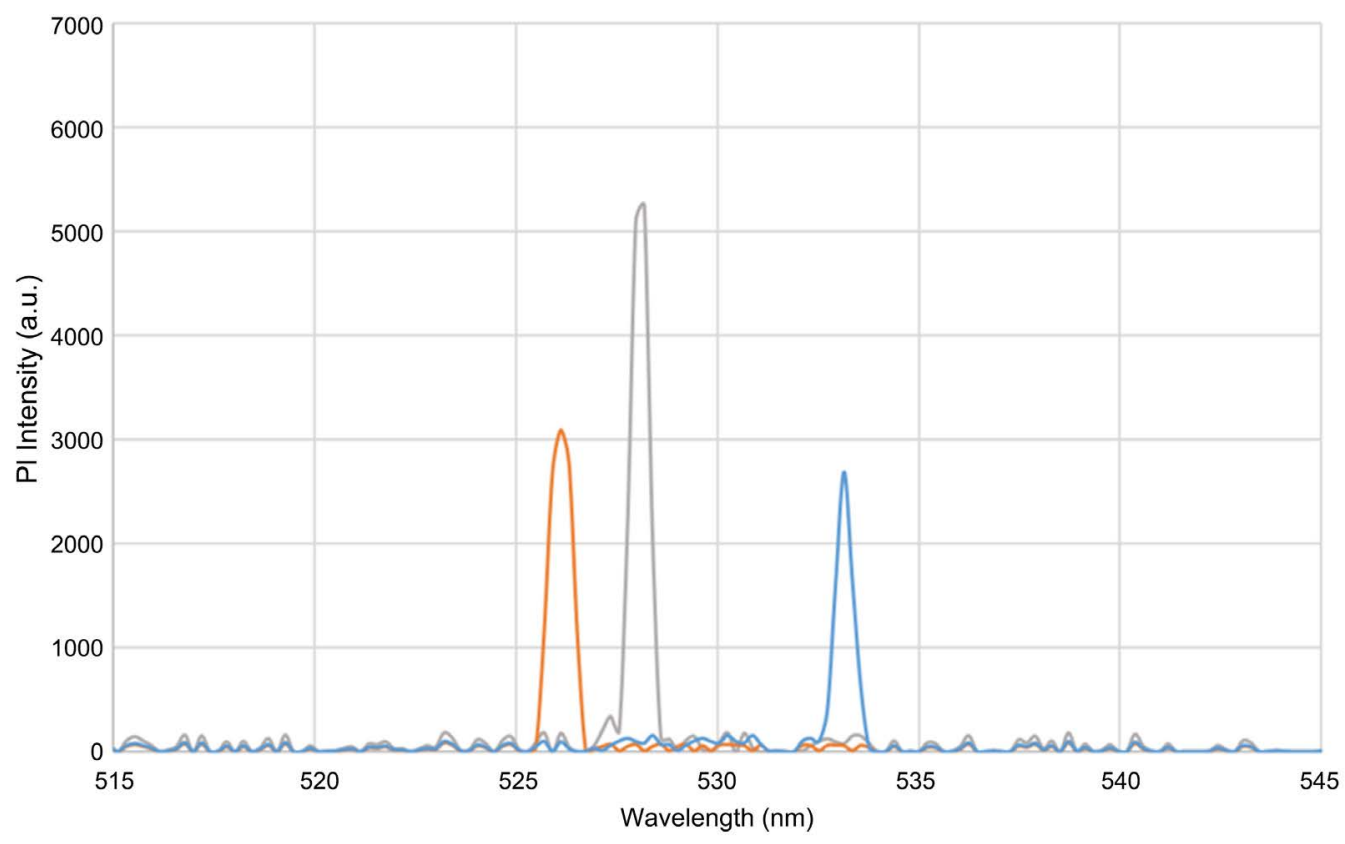

$-\mathrm{N}_{2}-\mathrm{O}_{2}-$ Air

Figure 13. PL Spectra of $\mathrm{Cu}_{2} \mathrm{O}$ thin films (annealed at $300^{\circ} \mathrm{C}$ ).

Using the spectrometer software, the following specs were adjusted: integration time of $400 \mathrm{~ms}$ and reference spectrum stored as a background spectrum. The PL peaks results observed are shown in Table 3: 
$400^{\circ} \mathrm{C}$

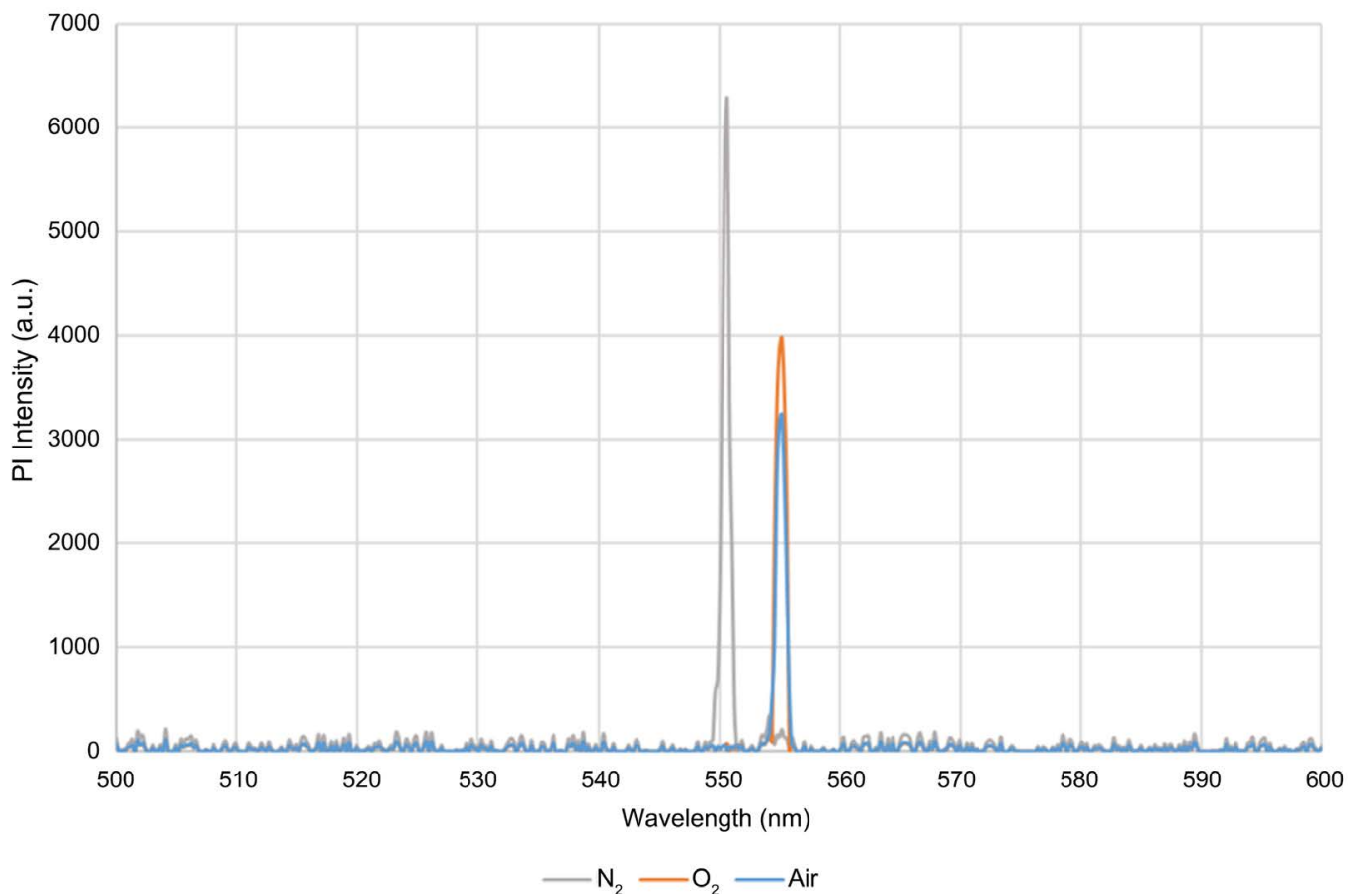

Figure 14. PL Spectra of $\mathrm{Cu}_{2} \mathrm{O}$ thin films (annealed at $400^{\circ} \mathrm{C}$ ).

Table 3. $\mathrm{Cu}_{2} \mathrm{O}$ thin films PL peaks.

\begin{tabular}{cccc}
\hline \multirow{2}{*}{ Temperature } & \multicolumn{3}{c}{ PL Peaks } \\
\cline { 2 - 4 } & Air & $\mathrm{O}_{2}$ & $\mathrm{~N}_{2}$ \\
\hline Room Temperature & $478 \mathrm{~nm}$ \\
$100^{\circ} \mathrm{C}$ & $488 \mathrm{~nm}$ & $485 \mathrm{~nm}$ & $483 \mathrm{~nm}$ \\
$200^{\circ} \mathrm{C}$ & $488 \mathrm{~nm}$ & $485 \mathrm{~nm}$ & $488 \mathrm{~nm}$ \\
$300^{\circ} \mathrm{C}$ & $533 \mathrm{~nm}$ & $526 \mathrm{~nm}$ & $528 \mathrm{~nm}$ \\
$400^{\circ} \mathrm{C}$ & $555 \mathrm{~nm}$ & $555 \mathrm{~nm}$ & $550 \mathrm{~nm}$ \\
\hline
\end{tabular}

The effects of the annealing temperature were noticeable and overall there was shift from a lower spectrum peak $(478 \mathrm{~nm})$ for the thin film created in air, to 483 $\mathrm{nm}$ at $100^{\circ} \mathrm{C}$ and all the way to $550 \mathrm{~nm}$ at $400^{\circ} \mathrm{C}$ for the film annealed in nitrogen $\left(\mathrm{N}_{2}\right)$. If the annealing temperature is increased even higher than $400^{\circ} \mathrm{C}$, an even higher PL peak for the $\mathrm{Cu}_{2} \mathrm{O}$ thin films can be achieved, which will transition the output spectrum to upper visible and even infrared. The increase in the annealing temperature induces the formation of a more hard packed structure. The sharper peaks obtained for the thin films annealed at $400^{\circ} \mathrm{C}$ indicate a higher uniformity of the composition and strain.

The results are similar with other investigations of similar types of films (300 $\mathrm{nm}$ to $700 \mathrm{~nm}$ range) [13]. The difference between the three types of films was the following: annealed in air and in oxygen $\left(\mathrm{O}_{2}\right)$ produced the lower intensity peaks (orange and blue colors) and the films annealed in nitrogen $\left(\mathrm{N}_{2}\right)$ produced 
a higher intensity peak (gray color) at almost the same wavelengths. The PL emission peaks are attributed to the recombination of the phonon-assisted excitons in the $\mathrm{Cu}_{2} \mathrm{O}$ layer. It corresponds to the transition between ${ }^{3} \Gamma_{5}^{+}$valence band to ${ }^{2} \Gamma_{7}^{+}$conduction band in $\mathrm{Cu}_{2} \mathrm{O}$ crystals [14].

Raebiger et al. [15] calculations on $\mathrm{Cu}_{2} \mathrm{O}$ show that the intrinsically copper-deficient nature is due to formation of copper vacancies $\left(\mathrm{V}_{\mathrm{Cu}}\right)$. These copper vacancies would act as a shallow and efficient hole producer. The $\mathrm{Cu}_{2} \mathrm{O}$ is intrinsically p-type because the oxygen vacancies $\left(\mathrm{V}_{\mathrm{O}}\right)$ which are potential hole destroyers have no transition level in the gap and thus cannot annihilate holes. The other possible hole destroyer copper interstitials $\left(\mathrm{Cu}_{\mathrm{i}}\right)$ has high formation energy associated with deep transition level and would thus, be incapable to destroy holes efficiently created by $\mathrm{V}_{\mathrm{Cu}}$ [16].

Photoconductivity and deep level transient spectroscopy studies shows the presence of holes laying between $0.45 \mathrm{eV}$ and $0.55 \mathrm{eV}$ above the top of the valence band. These are due to $\mathrm{Cu}$ vacancies and as a result, the PL spectra of $\mathrm{Cu}_{2} \mathrm{O}$ films show free excitons and bound excitons in the region between 450 to 650 $\mathrm{nm}$ in the visible spectrum [16].

Dolai et al. [16] observed PL peaks located at $551 \mathrm{~nm}(2.25 \mathrm{eV})$ and $543 \mathrm{~nm}$ $(2.28 \mathrm{eV})$. These peaks were assigned to $\mathrm{V}_{\mathrm{Cu}}[16]$.

\section{Conclusion}

In this work, the optical properties of the $\mathrm{Cu}_{2} \mathrm{O}$ thin films were investigated. The optical bandgap for the $\mathrm{Cu}_{2} \mathrm{O}$ thin films was found to be between $2.23 \mathrm{eV}$ and $2.56 \mathrm{eV}$, which allows for potential applications in photovoltaic solar conversion. The optical bandgap varied as a function of temperature and the gas introduced during the annealing process. The introduction of different gases in the annealing chamber affected the quality and the optical properties of the $\mathrm{Cu}_{2} \mathrm{O}$ thin film. The differences between the air and the oxygen $\left(\mathrm{O}_{2}\right)$ were minor; however, the largest impact was created by the introduction of the nitrogen $\left(\mathrm{N}_{2}\right)$ gas in the annealing process. The annealing temperature had a severe impact on the films as well. The increase in annealing temperature created darker, more opaque films (in the visible spectrum) which shows that by decreasing the optical transmission, the absorption of energy will be increased. The source of this energy can be in the infrared portion of the solar spectrum. For further investigations, an analysis/comparison with copper oxide $(\mathrm{CuO})$ thin films should be explored as well.

\section{Acknowledgements}

This research was supported by the Electrical and Computer Engineering Department at University of Central Florida.

\section{Conflicts of Interest}

The authors declare no conflicts of interest regarding the publication of this paper. 


\section{References}

[1] Perng, D.-C., Hong, M.-H., Chen, K.-H. and Chen, K.-H. (2017) Enhancement of Short-Circuit Current Density in $\mathrm{Cu}_{2} \mathrm{O} / \mathrm{ZnO}$ Heterojunction Solar Cells. Journal of Alloys and Compounds, 695, 549-554. https://doi.org/10.1016/j.jallcom.2016.11.119

[2] Gu, Y., Su, X., Du, Y.L. and Wang, C.M. (2010) Preparation of Flower-Like $\mathrm{Cu}_{2} \mathrm{O}$ Nanoparticles by Pulse Electrodeposition and Their Electrocatalytic Application. Applied Surface Science, 256, 5862-5866. https://doi.org/10.1016/j.apsusc.2010.03.065

[3] Srinivasan, S.S.G., Govardhanan, B., Ashok, M. and Santhosh Kumar, M.C. (2021) Influence of Deposition Time on the Visible-Light-Driven Photocatalytic Activity of $\mathrm{Cu}_{2} \mathrm{O}$ Thin Films by Reactive Sputtering at Room Temperature. Materials Letters, 284, Article ID: 128980. https://doi.org/10.1016/j.matlet.2020.128980

[4] Martínez-Saucedo, G., Torres-Castanedo, C.G., Arias-Cerón, S., Castanedo-Pérez, R., Torres-Delgado, G. and Zelaya-Ángel, O. (2019) Photoluminescence of $\mathrm{Cu}_{2} \mathrm{O}$ Nanostructured in Stressed Thin Films Induced by Temperature. Journal of Luminescence, 215, Article ID: 116642. https://doi.org/10.1016/j.jlumin.2019.116642

[5] Yang, Y.Y., Li, Y.N. and Pritzker, M. (2016) Control of $\mathrm{Cu}_{2} \mathrm{O}$ Film Morphology Using Potentiostatic Pulsed Electrodeposition. Electrochimica Acta, 213, 225-235. https://doi.org/10.1016/j.electacta.2016.07.116

[6] Ozaslan, D., Erken, O., Gunes, M. and Gumus, C. (2020) The Effect of Annealing Temperature on the Physical Properties of $\mathrm{Cu}_{2} \mathrm{O}$ Thin Film Deposited by SILAR Method. Physica B: Condensed Matter, 580, Article ID: 411922. https://doi.org/10.1016/j.physb.2019.411922

[7] Kumar, R., Bergum, K., Riise, H.N., Monakhov, E., Galeckas, A. and Svensson, B.G. (2020) Impact of Post Annealing and Hydrogen Implantation on Functional Properties of $\mathrm{Cu}_{2} \mathrm{O}$ Thin Films for Photovoltaic Applications. Journal of Alloys and Compounds, 825, Article ID: 153982. https://doi.org/10.1016/j.jallcom.2020.153982

[8] Tonagi, D., Hagiwara, M. and Fujihara, S. (2020) Fabrication of Highly (111)-Oriented $\mathrm{Cu}_{2} \mathrm{O}$ Films on Glass Substrates by Repeated Chemical Bath Deposition. Journal of Crystal Growth, 551, Article ID: 125920. https://doi.org/10.1016/j.jcrysgro.2020.125920

[9] Sancho-Parramon, J., Janicki, V. and Zorc, H. (2008) Compositional Dependence of Absorption Coefficient and Band-Gap for $\mathrm{Nb}_{2} \mathrm{O}_{5}-\mathrm{SiO}_{2}$ Mixture Thin Films. Thin Solid Films, 516, 5478-5482. https://doi.org/10.1016/j.tsf.2007.07.028

[10] Viezbicke, B.D., Patel, S., Davis, B.E. and Birnie, D. (2015) Evaluation of the Tauc Method for Optical Absorption Edge Determination: ZnO Thin Films as a Model System. Physica Status Solidi B, 252, 1700-1710. https://doi.org/10.1002/pssb.201552007

[11] Ait Hssi, A., Atourki, L., Labchir, N., Abouabassi, K., Ouafi, M., Mouhib, H., Ihlal, A., Elfanaoui, A., Benmokhtar, S. and Bouabid, K. (2020) Structural and Optical Properties of Electrodeposited $\mathrm{Cu}_{2} \mathrm{O}$ Thin Films. Materials Today. Proceedings, 22, 89-92. https://doi.org/10.1016/j.matpr.2019.08.100

[12] Ait Hssi, A., Atourki, L., Abouabassi, K., Elfanaoui, A., Bouabid, K., Ihlal, A., Benmokhtar, S. and Ouafi, M. (2018) Growth and Characterization of $\mathrm{Cu}_{2} \mathrm{O}$ for Solar Cells Applications. AIP Conference Proceedings, 2056, Article ID: 020006. https://doi.org/10.1063/1.5084979

[13] Butte, M. and Waghuley, S.A. (2020) Optical Properties of $\mathrm{Cu}_{2} \mathrm{O}$ and $\mathrm{CuO}$. AIP Conference Proceedings, 2220, Article ID: 020093.

https://doi.org/10.1063/5.0001644 
[14] Prabu, R.D., Valanarasu, S., Ganesh, V., Shkir, M., Kathalingam, A. and Al Faify, S. (2018) Effect of Spray Pressure on Optical, Electrical and Solar Cell Efficiency of Novel $\mathrm{Cu}_{2} \mathrm{O}$ Thin Films. Surface and Coatings Technology, 347, 164-172. https://doi.org/10.1016/j.surfcoat.2018.04.084

[15] Raebiger, H., Lany, S. and Zunger, A. (2007) Origins of the p-Type Nature and Cation Deficiency in $\mathrm{Cu}_{2} \mathrm{O}$ and Related Materials. Physical Review B, 76, Article ID: 045209. https://doi.org/10.1103/PhysRevB.76.045209

[16] Dolai, S., Das, S., Hussain, S., Bhar, R. and Pal, A.K. (2017) Cuprous Oxide $\left(\mathrm{Cu}_{2} \mathrm{O}\right)$ Thin Films Prepared by Reactive D.C. Sputtering Technique. Vacuum, 141, 296-306. https://doi.org/10.1016/j.vacuum.2017.04.033 